\title{
OPEN
}

\section{Author Correction: PIC\&RUN: An integrated assay for the detection and retrieval of single viable circulating tumor cells}

Mohamed Kamal, Shahin Saremi, Remi Klotz, Oihana Iriondo, Yonatan Amzaleg,
Yvonne Chairez, Varsha Tulpule, Julie E. Lang, Irene Kang \& Min Yu

Correction to: Scientific Reports https://doi.org/10.1038/s41598-019-53899-4, published online 25 November 2019

This Article contains a typographical error in the Introduction where,

"Currently, to isolate single live CTCs, additional purification steps, such as the DEPArray ${ }^{34,35}$, Fluidigm C1 ${ }^{36-39}$, ALS cell-Selector ${ }^{40}$ or single-cell micro-manipulation, are typically used."

should read:

"Currently, to isolate single live CTCs, additional purification steps, such as the DEPArray ${ }^{34,35}$, Fluidigm $\mathrm{Cl}^{36-39}$, ALS CellCelector ${ }^{40}$ or single-cell micro-manipulation, are typically used."

(c) (i) Open Access This article is licensed under a Creative Commons Attribution 4.0 International License, which permits use, sharing, adaptation, distribution and reproduction in any medium or format, as long as you give appropriate credit to the original author(s) and the source, provide a link to the Creative Commons license, and indicate if changes were made. The images or other third party material in this article are included in the article's Creative Commons license, unless indicated otherwise in a credit line to the material. If material is not included in the article's Creative Commons license and your intended use is not permitted by statutory regulation or exceeds the permitted use, you will need to obtain permission directly from the copyright holder. To view a copy of this license, visit http://creativecommons.org/licenses/by/4.0/.

(C) The Author(s) 2020 